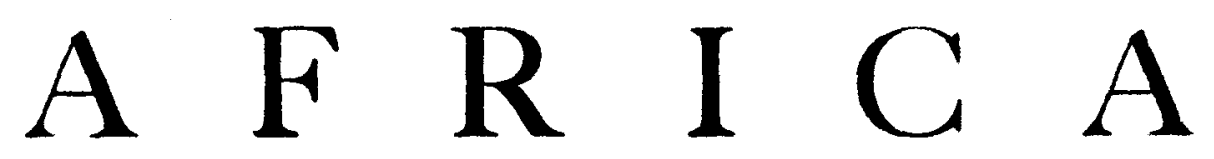

JOURNAL OF THE INTERNATIONAL AFRICAN INSTITUTE

\title{
OBITUARY
}

\section{ANTÓNIO AUGUSTO MENDES CORREIA}

W ITH the death early this year, at the age of $7 \mathrm{I}$, of Professor Mendes Correia, Emeritus Professor and Director of the Institute of Advanced Overseas Studies in Lisbon, both Portugal and anthropological studies have suffered a great loss.

Professor Mendes Correia was the leading personality in anthropology in Portugal over the past forty-five years, exercising an extraordinary influence in this field until his last days. He was endowed with exceptional intellectual qualities, to which were allied an enormous capacity for work and a great enthusiasm for knowledge. During his years at the Faculty of Sciences at Oporto he organized the Museum and the Laboratory of Anthropology, Ethnology, and Archaeology. In 1918 he founded the Portuguese Society of Anthropology and Ethnology and a year later its journal, Antropologia e Etnologia, the last number of which (vol. xvii, 1959) was published in his honour.

He took charge of the organization of the XVth International Congress of Anthropology and Prehistoric Archaeology and the IVth International Session of Anthropology in 1930. In 1934 he organized the Ist National Congress of Colonial Anthropology in the city of Oporto. In 1945 he founded the Centre of Studies in Peninsular Ethnology, of which he became President. In 1946 he was appointed Director of the Advanced Overseas Studies Institute in Lisbon.

He was a Member of the Overseas Council, President of the 'Junta de Missões e Investigacões Ultramarinas' and President of the Geographical Society. He had been also for many years a member of the Executive Council of the International African Institute.

Although Mendes Correia had worked mainly in physical anthropology and prehistoric archaeology he did not neglect ethnology, for he was an anthropologist lato sensu, as one may see from his bibliography of more than 300 works.

His great knowledge, the elegance of his prose, his eloquence, and his affability in his relations with everybody, gained him great popularity and a wide reputation, not only in his own country but abroad. During his life he received many demonstrations of respect and consideration and was elected doctor honoris causa by the Universities of Lyon, Montpellier, and the Witwaterstand, and member of several Academies and Institutions in Portugal, Spain, Brazil, France, Italy, England, Germany, Belgium, and Austria.

JORGE DIAS

'Africa', the Journal of the International African Institute, is published by the Institute, but' except where otherwise stated the writers of the articles are responsible for the opinions expressed. 